\title{
В. В. Поліщук
}

УДК 004:630*5 доктор с.-г. наук, професор кафедри садовопаркового господарства, Уманський національний університет садівництва (м. Умань), Україна E-mail: pol.val@i.ua

М. В. Шемя кін кандидат с.-г. наук, доцент кафедри геодезії, картографії і кадастру, Уманський національний університет садівництва (м. Умань), Україна E-mail: misha.uman@gmail.com

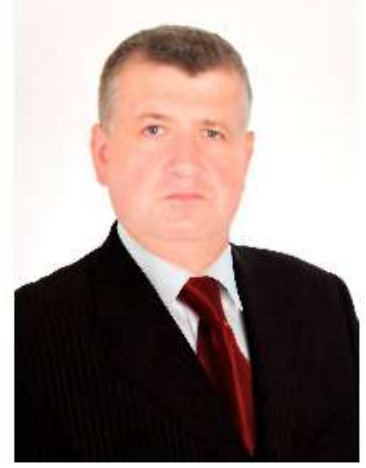

\section{В. П. Шпак}

викладач кафедри лісового господарства, Уманський національний університет садівництва (м. Умань), Україна E-mail: forestry@udau.edu.ua

I. В. Козаченко кандидат с.-г. наук, доцент кафедри лісового господарства, Уманський національний університет садівництва

(м. Умань), Україна E-mail: kozachenko_irina79@ukr.net

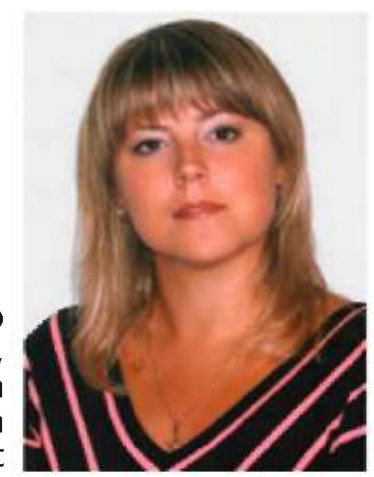

\section{ДОСВІД ЗАСТОСУВАННЯ ІТ-ТЕХНОЛОГІЙ В ЛІСОВІЙ ТАКСАЦІЇ НА ПРИКЛАДІ ДП «ЗОЛОТОНІСЬКЕ ЛІСОВЕ ГОСПОДАРСТВО»}

\begin{abstract}
Анотація. У роботі звернуто увагу на зміну вимогдо лісоуправління і лісокористування, цілеспрямованого регулювання лісових екосистем. Розглянуто підходи до вибору методів відведення лісосік у рубання головного користування. Зазначено фактори, що впливають на вибір методу відведення лісосік у рубання головного користування: кліматичні умови регіону; охорона праці; особливості рельєфу; людський чинник. Висвітлено питання застосування ITтехнологій у лісовому господарстві, переваги та напрямки використання геоінформаційних систем, а також шляхи поповнення лісових геоінформаційних систем оперативною інформацією при актуалізації лісового фонду, про стан лісових насаджень, проведення робіт із лісової таксації і контролю за якістю відводів лісосік головного користування в підрозділах держлісгоспів та лісовпорядкування, вогнища шкідників чи хвороб, санітарний стан лісів, для моніторингу та екологічного прогнозу, для обліку рідкісних видів тварин і рослин та визначення оптимальних умов ї проживання, для опрацювання методів аналізу альтернативних варіантів господарського впливу на ліси.

Зазначено важливість картографічної інформації, яку постійно необхідно поєднувати з базами даних, що є вагомою ланкою організації і планування робіт у лісовому господарстві при відведенні лісосік головного користування $і$ контролі за якістю ї відведення та при проведенні лісовпорядкувальних робіт. у роботі наведено послідовність робіт при відведенні лісосік головного користування: підбір лісосік у рубання згідно з встановленими «Правилами рубок головного користування в лісах України», відмежування вибраних'ділянок на місцевості, суцільний перелік'дерев, заміри модельних дерев 'для визначення розряду висот, проведення матеріально-грошової оцінки лісосіки з оформленням всієі необхідної документації. Обгрунтовано та практично доведено можливість застосування Iт. технологій при відведенні лісосік головного користування та складних лісотаксаційних робіт: підбір ділянок у відводи лісосік у цілому, створення повидільної бази даних, сумісної з цифровою картою лісництва шляхом ручної векторизації на створеній цифровій карті лісництва, визначення основних таксаційних показників насадження (середній діаметр, середня висота, склад $і$ вік насадження, форма насадження, бонітет, повнота, приріст), матеріально-грошова оцінка лісосіки, контроль за якістю проведення лісовпорядкувальних робіт. у логічній послідовності викладено порядок проведення вказаних робіт при застосуванні програмного забезпечення «ИнГео» у виробничих умовах.
\end{abstract}

ключові. слова: геоінформаційна система, програмне забезпечення, таксаційний опис, матеріально-грошова оцінка.

В. В. Полищук

доктор с.-х. Н., профессор кафедры садово-паркового хозяйства Уманского национального университета садоводства (г. Умань), Украина

М. В. Шемя кин

кандидат с.-х. наук, доцент кафедры геодезии, картографии и кадастра Уманского национального университета садоводства (г. Умань), Украина

В. П. Шпак

преподаватель кафедры лесного хозяйства Уманского национального университета садоводства (г. Умань), Украина И. В. Козаченко

кандидат с.-х. наук, доцент кафедры лесного хозяйства Уманского национального университета садоводства (г. Умань), Украина 


\section{ПРИМЕНЕНИЕ ІТ-ТЕХНОЛОГИЙ В ЛЕСНОЙ ТАКСАЦИИ В ГП «ЗОЛОТОНОШСКОЕ ЛЕСНОЕ ХОЗЯЙСТВО»}

Аннотация. В работе обращено внимание на изменение требований к лесоуправлению и лесопользованию, целенаправленному регулированию лесных экосистем. Рассмотрены подходы к выбору методов отвода лесосек в рубку главного пользования. Указано факторы, влияющие на выбор метода отвода лесосек в рубку главного пользования: климатические условия региона, охрана труда, особенности рельефа, человеческий фактор. Освещены вопросы применения IT-технологий в лесном хозяйстве, преимущества и направления использования геоинформационных систем, а также пути пополнения лесных геоинформационных систем оперативной информацией при актуализации лесного фонда, о состоянии лесных насаждений, проведении работ по лесной таксации и контроле качества отводов лесосек главного пользования в подразделениях гослесхозов и лесоустройстве, очагах вредителей или болезней, санитарноом состоянии лесов, для мониторинга и экологического прогноза, для учета редких видов животных и растений, определения оптимальных условий их проживания, для обработки методов анализа альтернативных вариантов хозяйственного воздействия на леса.

Указано важность картографической информации, которую постоянно необходимо сочетать с базами данных. Она является весомым звеном организации и планирования работ в лесном хозяйстве при отводе лесосек главного пользования и контроле за качеством их отвода и при проведении лесоустроительных работ. В работе приведены последовательность работ при отводе лесосек главного пользования: подбор лесосек в рубку в соответствии с установленными «Правилами рубок главного пользования в лесах Украины», размежевание выбранных участков на местности, сплошной перечень деревьев, замеры модельных деревьев для определения разряда высот, проведение материально-денежной оценки лесосеки с оформлением всей необходимой документации. Обоснована и практически доказана возможность применения IТ технологий приотводелесосекглавного пользования и сложныхлесотаксационных работах: подбор участков в отводы лесосек в целом, создание поотводной базы данных, совместимой с цифровой картой лесничества путем ручной векторизации на созданной цифровой карте лесничества, определение основных таксационных показателей насаждения (средний диаметр, средняя высота, состав и возраст насаждения, форма насаждения, бонитет, полнота, прирост), материально-денежная оценка лесосеки, контроль по качеству проведения лесоустроительных работ. В логической последовательности изложены порядок проведения указанных работ при применении программного обеспечения «ИнГео» в производственных условиях.

ключевые слова: геоинформационная система, программное обеспечение, таксационное описание, материальноденежная оценка,

\section{V. Polishchuk}

Doctor of Agricultural Sciences, Professor of Department of Landscape Gardening of Uman National University of Horticulture (Uman), Ukraine

\section{V. Shemyakin}

PhD of Agricultural Sciences, Associate Professor of Department Geodesy, Cartography and Cadastre of Uman National University of Horticulture (Uman), Ukraine

V. P. Shpak

Teacher of Department of Forestry of Uman National University of Horticulture (Uman), Ukraine

I. V. Kozachenko

$\mathrm{PhD}$ of Agricultural Sciences, Associate Professor of Uman National University of Horticulture (Uman), Ukraine

\section{APPLICATION OF IT-TECHNOLOGIES IN FOREST TAXATION OF SE «ZOLOTONISCHE FOREST \\ FARM»}

Abstract. The paper draws attention to changing requirements for forest management and forest using, targeted regulation of forest ecosystems. Approaches to the choice allocation methods of the felling area into main use cutting are considered. Factors that influence the choice allocation methods of the felling area into main use cutting are indicated: climatic conditions of the region, labor protection, features of relief, human factor. Application issues of IT, technologies in forestry, advantages and directions of use of geographic information systems, as well as ways to replenish forest geoinformation systems by operational information when updating the forest fund, about state of the forest plantations, carrying out works on forest tax and control to the quality of the felling area into main using in the departments of state forestry and forest management, accumulation of pests or diseases, sanitary condition of forests, for monitoring and environmental forecast, to account for rare species of animals and plants and to determine the optimal conditions for their habitation, for elaboration of methods of analysis of alternative variants of economic influence on forests are covered.

The importance of cartographic information which is constantly necessary to combine with databases, which is an important link in the organization and planning of forestry at the assignation of the main use felling area and control over the quality of their assignation and in conducting forest management works is indicated. The paper gives a sequence of work for the allocation of the main use felling area: selection of the felling area in cutting according to established «The rules of the main use cutting in the forests of Ukraine», demarcation of the selected areas on the ground, complete list of trees, measurement of model trees to determine the height category, conducting a monetary evaluation of the felling area with the registration of all the necessary documentation. The ability to apply IT technology to allocation the main use felling area and complex forest- taxation works is substantiated and practically proved; selection of plots to allocation of the felling area as a whole, creation of a database, which is compatible with the digital forestry map by manual vectorization on the created digital map of the forestry, determination of basic taxonomic indices of planting (average diameter, average height, composition and age of planting, form of planting, bonite, completeness, growth), material evaluation of the felling area, control over the quality of forest management operations. In the logical sequence, the order of carrying out the specified works is outlined when applying software «InGeo» in the production environment.

Key words: geoinformation system, software, taxation description, material evaluation.

Постановка проблеми. Нині, на нашу думку, конкретних методів відведення лісосік у рубання головного користування немає. у кожного лісгоспу буде своя методика проведення таких заходів. Це зумовлюється такими чинниками як кліматичні умови регіону, охорона праці, особливості рельєфу, людський фактор. Але, де 6 не знаходився лісгосп можна прослідкувати певний алгоритм дій пов'язаних з відведенням лісосік, Цей алгоритм передбачає наступну послідовність:

- підбір лісосік у рубання згідно з встановленими «Правилами рубок головного користування в лісахУкраїни»; - відмежування вибраних ділянок на місцевості;

- суцільний облік дерев;

- заміри модельних дерев для визначення розряду ви- 
COT;

- проведення матеріально-грошової оцінки лісосіки 3 оформленням всієї необхідної документації.

Однак, нині ІТ технології при проведенні робіт з таксації та контролю за лісовпорядкуванням мало поширені, що вимагає оприлюднення досвіду їх застосування у виробництві.

Аналіз останніх досліджень та публікацій. Концепція сталого розвитку лісів передбачає збалансоване та неперервне використання всіх ресурсів і екологічних властивостей лісу і, водночас, виключає зниження стійкості та біорізноманіття лісових екосистем, зменшення ролі лісового покриву в регулюванні природних процесів.

Зміна підходів до лісоуправління і лісокористування, цілеспрямоване регулювання лісових екосистем вимагає перегляду принципів організації інформаційного забезпечення лісового господарства, опрацювання методів аналізу альтернативних варіантів господарського впливу на ліси. Такий аналіз можливий при поєднанні картографічної інформації і баз даних про об'єкти лісового фонду, що надають геоінформаційні системи (ГIC) [2, 11].

Вагомою ланкою організації і планування робіт у лісовому господарстві $€$ картографічна інформація, яку постійно необхідно поєднувати з базами даних (таксаційні описи, зведені відомості тощо). ГІС дає змогу здійснювати пошук у базах даних і просторові запити в дуже короткі терміни, виявляти взаємозв'язки між різними параметрами (рослинністю, ґрунтами, кліматом) [1, 2, 12].

Завдяки ГІС лісові підприємства отримують інструмент, за допомогою якого розраховують та контролюють оптимальне користування лісом з урахуванням екологічних та економічних чинників.

Особливо актуальним $€$ використання ГІС технологій для оцінки швидкозмінних ситуацій у лісовому фонді: при актуалізації лісового фонду; появі вогнищ шкідників чи хвороб; для визначення санітарного стану лісів; для моніторингу та екологічного прогнозу; для обліку рідкісних видів тварин і рослин та визначення оптимальних умов їх проживання; контролю за роботою і результатами лісовпорядкування [4, $6,11]$.

Останнім часом почалося освоєння повидільної бази на операційній системі Android, яка встановлена на широкоекранному смартфоні, або планшеті (рис. 1).

Вона дає змогу переглянути таксаційну характеристику на місцевості, за наявності лише смартфону, замість планшетів і громіздких таксаційних описів. Також можна скористатись функцією GPS і визначити своє місцезнаходження безпосередньо на карті і виконати елементарне знімання
[1].

Впровадження ГІС технологій у лісовому господарстві дозволить значно зменшити трудомісткість, скоротити час і підвищити точність складних робіт з таксації та миттєво визначати координати об'єктів.

Мета статті. Висвітлити застосування сучасних методів таксації лісових насаджень, основаних на застосуванні ITтехнологій, що дозволяє виконувати швидко і з великою точністю складні роботи з таксації лісу та орієнтуватись у незнайомих масивах.

Методика досліджень. Таксаційні показники насаджень, необхідні для одержання їхньої характеристики, виконували за загальноприйнятими методиками [3].

Для створення ПС бази даних використовували план лісонасаджень і таксаційний опис Ліплявського лісництва, а також топографічні карти масштабу 1:25000.

У середовищі прикладної програми ГІС "ИнГео" на основі плану лісових насаджень шляхом ручної векторизації на створеній цифровій карті Ліплявського лісництва, використовуючи таксаційний опис лісництва, «прив'язали» до створених векторних об'єктів семантичну інформацію про них. На основі введених у програму даних була створена повидільна база даних, яка сумісна з цифровою картою лісництва. У подальшому ця база використовувалась для розрахунків таксаційних показників, матеріально-грошової оцінки лісосік.

Основні результати дослідження. Підбір лісосік у рубання. Використовуючи фонд стиглого лісу [9], призначеного під головне користування лісовпорядкуванням, спеціалістами (інженерами) лісгоспу була проведена попередня нарізка лісосік у камеральних умовах. При цьому враховувались організаційно-технічні показники лісосіки згідно з «Правилами рубок головного користування в лісах України» [10] - розміщення лісосіки, ширина та довжина лісосіки, їі площа. Підбір ділянок і відводи в цілому проводили за допомогою програмного забезпечення "ИнГео" [5]. Зазначена програма зв'язана з таксаційною електронною базою. В результаті цього в електронному вигляді мали такі матеріали лісовпорядкування - таксаційна характеристика виділу та повидільна база в цілому, картографія та інше (рис. 2).

На основі таксаційних даних про запас деревини на 1 га та попередньо встановленої площі за допомогою програмного забезпечення визначали приблизний вирубуваний запас деревини з ділянки. Такі дії проводили з кожною ділянкою доки загальний запас вирубки з обраних ділянок відповідав розміру щорічної розрахункової лісосіки, з допустимими відхиленнями.

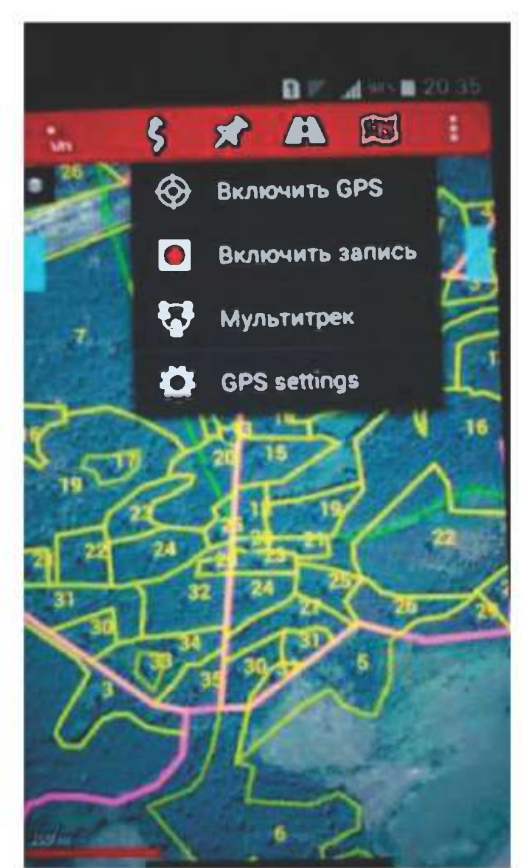

Рис. 1. Вигляд повидільної бази на OC Android 
Відмежування вибраних 'ділянок на місцевості. Для перенесення «нарізаних» ділянок 3 карти на місцевість використовували бусоль БГ-1, мірну стрічку довжиною 20 м, клеймо з відтиском ЛГ-1 (клеймо інженерів з підрозділу таксації і відведення лісосік), сокиру для затесування межі ділянки та туш для клейма.

Проклавши основний хід, проводили бусольне знімання за геоданими, одержаними при нарізанні в камеральних умовах, з одночасним затесуванням межі на деревах та клеймінням затесаних щік.

Після відмежування ділянки в натурі проводили суцільний облік дерев. Дані обліку записували методом точковки до польової облікової відомості у відповідні графи згідно з діаметром та категорії придатності (ділова, напівділова, дрова). Заміри діаметру проводли мірною вилкою, а різцем на деревах ставили затіски, що відповідають категоріям придатності: I - ділова; II - напівділова; III дрова.

Після цього проводили заміри модельних дерев для визначення розряду висот - щоб розрахувати матеріальну оцінку за сортиментними таблицями. Для визначення модельних дерев з даних суцільного обліку вибрали три дерева зі ступеня товщини з найбільшою кількістю дерев, і ще по три дерева нижчого і вищого ступенів товщини. Наприклад: ступінь 3 найбільшою кількістю дерев 32, тому модельні дерева були наступних діаметрів: 28 - 3 шт., 32 - 3 шт., 36
- 3 шт. Після встановлення модельних дерев робили заміри висоти висотоміром та записували у відомість.

Після того, як лісосіка відмежована в натурі, зроблений суцільний перелік дерев та виміряні модельні дерева, проводили обробку відводу, використовуючи програму "ИнГео" (рис. 3)

До неї вносили всі адресні дані ділянки, місце для яких виділено на рис. 3 червоним маркером. Програма самостійно, використовуючи дані з повидільної бази формувала зведену відомість разом з таксаційною характеристикою ділянки, рахувала вирубуваний запас за переліком і таксову вартість деревини.

Таксаційна характеристика досліджуваної ділянки. Розглянемо конкретний приклад, який ми обрали як дослідний матеріал для цієї роботи. Для цього ми взяли ділянку відведену під рубку головного користування на 2016 рік, що розташована в кварталі 31, виділ 4, ділянка 1 Ліплявського лісництва ДП «Золотоніське ЛГ» і яка на момент написання статті знаходиться в стадії розробки.

Згідно з останнім лісовпорядкуванням, в таксаційному описі кварталу 31 Ліплявського лісництва вказані всі таксаційні показники виділу 4, а саме:

Склад насадження - 10Сз+Дз+Акб+Бп;

Ярус - 1; Елемент лісу - Сз; Вік - 107 років (+3 роки);

Висота - 25 метрів; Діаметр - 32 см; Група віку - 7; Клас бонітету - 2;

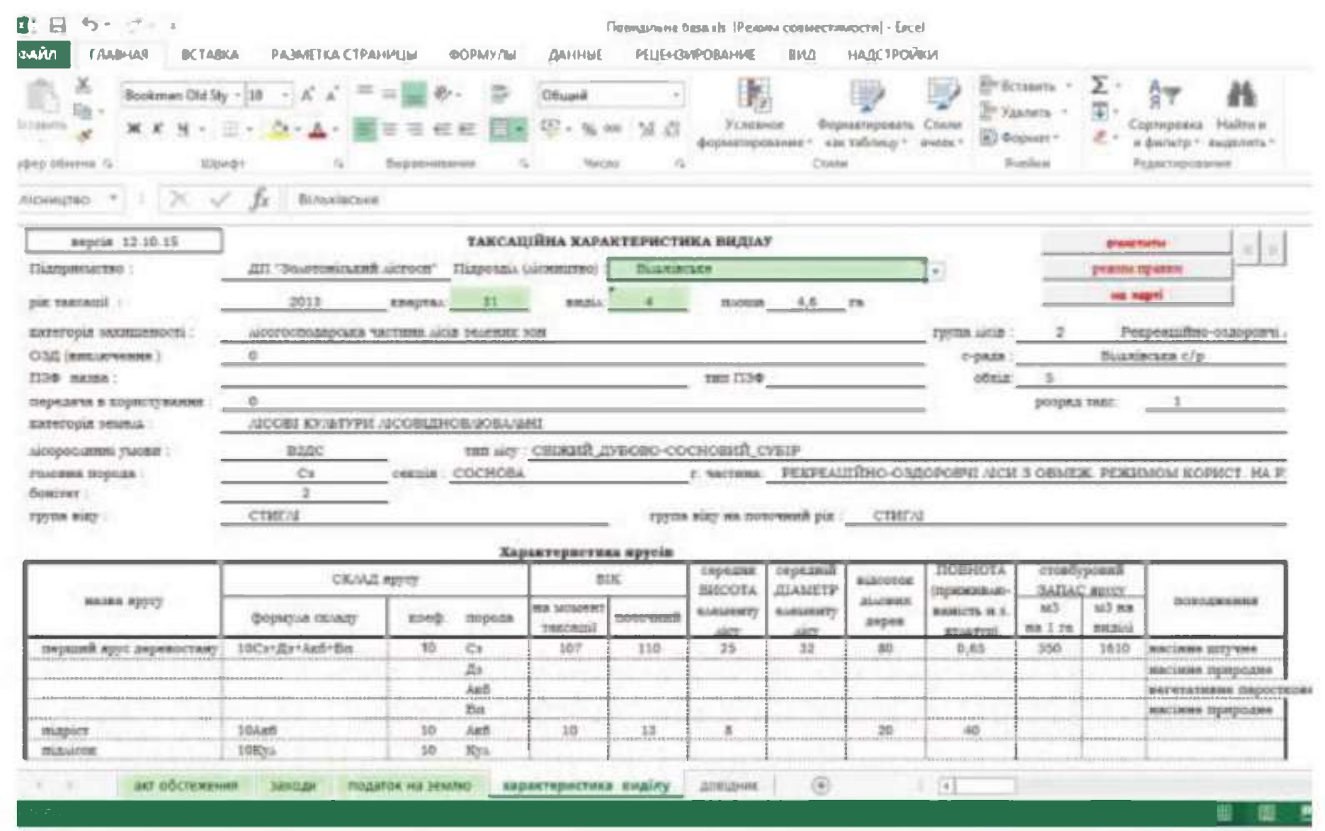

Рис. 2. Вигляд програмного забезпечення на моніторі комп'ютера

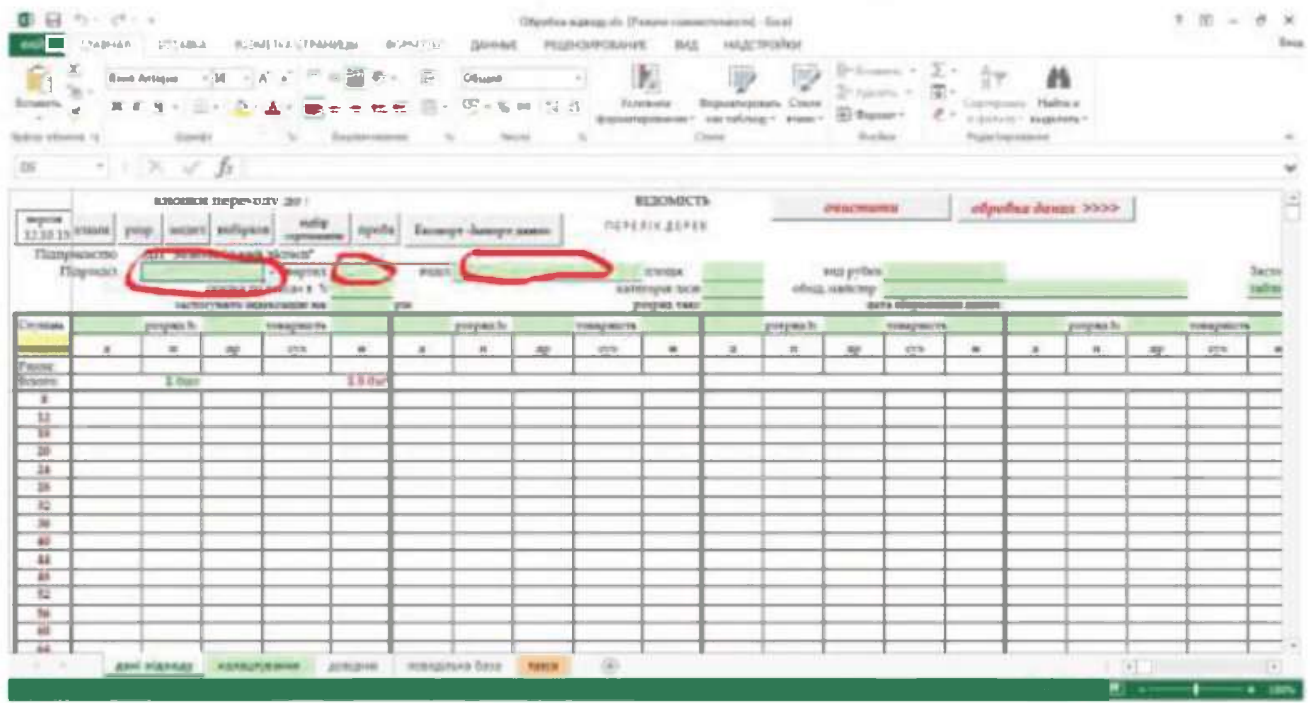

РИС. 3. Програма для проведення обробки відводу 
Тип лісу - В2ДС; Повнота - 0,65; Запас: на 1 га - 350 м³, на виділі - 1,61 тис. $\mathrm{M}^{3}$.

Отже насадження відповідає нормативам рубки головного користування, а саме: вік ділянки лісу на час рубання складає 110 років. Вирубуваний запас складає $350 \mathrm{~m}^{3} /$ га. Згідно з окомірною оцінкою таксаторів під час лісовпорядкування - цей запас придатний для головного користування.

Проведені дослідження повністю підтвердили достовірність даних проведеного лісовпорядкування.

Виконавши відвід ділянки під рубання, виконували камеральну обробку даних. Програмне забезпечення самостійно визначає таксаційні показники. На рис. 4 вказана функція виділена червоним маркером.

За отриманими даними таксаційна характеристика насадження виділу $є$ наступною (рис. 5):

Склад насадження - 10Сз+Акб+Дз+Бп;

Ярус - 1; Елемент лісу - Сз; Вік - 110 років;

Висота - 26 метрів; Діаметр - 36 см; Група віку - 7; Клас бонітету - 1 ;

Тип лісу - В2ДС; Повнота - 0,65; Запас : на 1 га - 303 $\mathrm{M}^{3}$, на виділі - 1,39 тис. $\mathrm{M}^{3}$.

Отже, можна зробити висновки:

- склад насадження незмінний;

- головна порода - Сз в 1 ярусі без змін;

- станом на 2013 рік (рік лісовпорядкування) вік насадження становив 107 років. 3 настанням 2016 року, програма автоматично додала 3 роки, а отже вік насадження становить 110 років, що відповідає дійсності;

- висота $\epsilon$ вищою на 1 метр, а середній діаметр на одну ступінь товщини більший. Таку різницю можна пояснити тим, що річний приріст за три роки після лісовпорядкування дав такі результати.

Запас на 1 га відрізняється від лісовпорядного на мінус $43 \mathrm{~m}^{3}$, що в загальному становить 13\% від проектного.
Це пояснюється тим, що в цьому виділі насадження дещо нерівномірне, з наявністю невеликих галявин та просвітів. Частина виділу, відведена під рубання, включала в себе три таких просвіти; також були сухостійні дерева, які впали, прогнили і вже віднесені до неліквідних, і не враховувалися до переліку.

Отже, на основі наведеного аналізу цієї ділянки, можна зробити висновок, що в цілому лісовпорядкування було проведено об'єктивно, з відхиленнями в допустимих межах. $€$ звичайно і виділи, в яких лісовпорядкування проведене недобросовісно, з дуже великою різницею до реального стану насаджень. Але ці недоліки виправляються в процесі безперервного лісовпорядкування, яке проводиться раз на рік із внесенням поточних змін. Не виправлені ділянки беруться до рубання за фактичними даними, в результаті чого розрахункова лісосіка може відрізнятися від запланованої. У загальному проведене лісовпорядкування можна вважати задовільним.

Камеральна обробка даних переліку досліджуваної лісосіки. Кінцевим етапом відводу лісосіки у рубання головного користування $€$ проведення матеріально-грошової оцінки лісосіки з оформленням всієї необхідної документації.

Після проведення польових робіт, проводили розрахунок матеріальної та зведеної відомості матеріально-грошової оцінки. Основою для проведення розрахунків $€$ польова облікова відомість та дані про заміри модельних дерев.

За замірами модельних дерев заповнювали відомість за допомогою «Сортиментних таблиць», визначали розряд висоти, за яким проводили розрахунок запасу за даними обліку [8]. Визначення розряду висоти можна провести і за допомогою програми для обробки відводу. Як видно за рис. 6 , функціональна кнопка для визначення розряду висоти позначена червоним маркером.

Після натискання на неї, з'явиться табличка вводу даних заміру модельних дерев - програма розраховує їх і видає

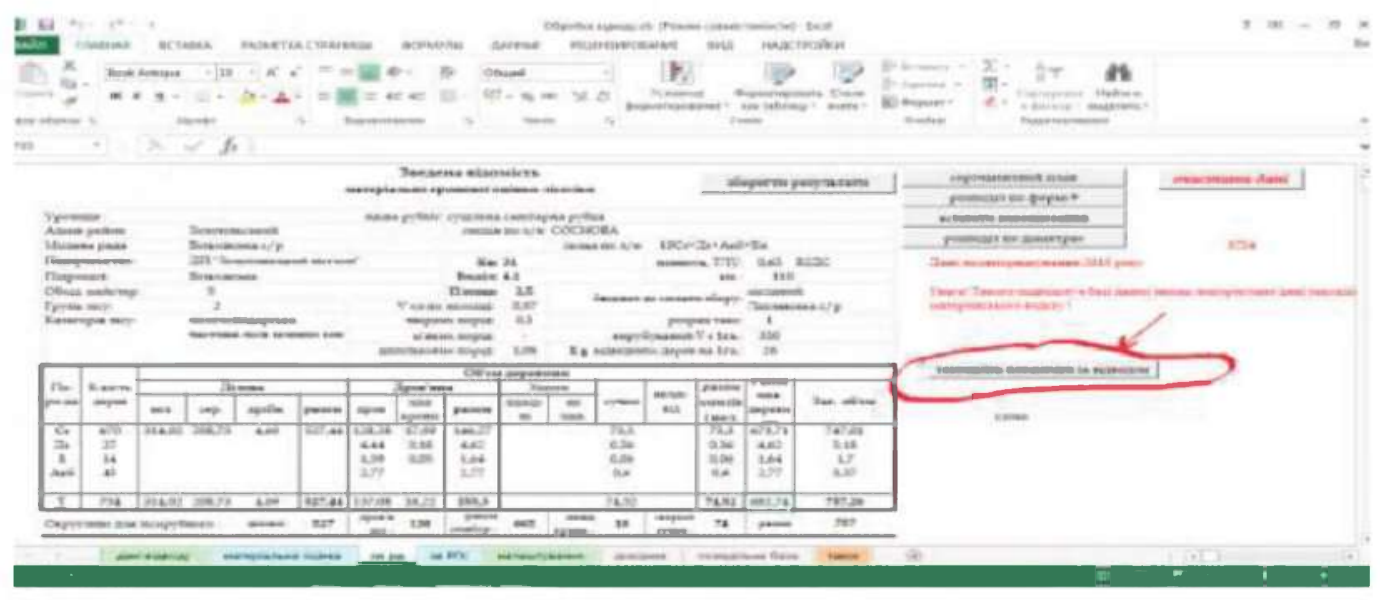

Рис. 4. Кнопка програми для визначення таксаційної характеристики за відводом

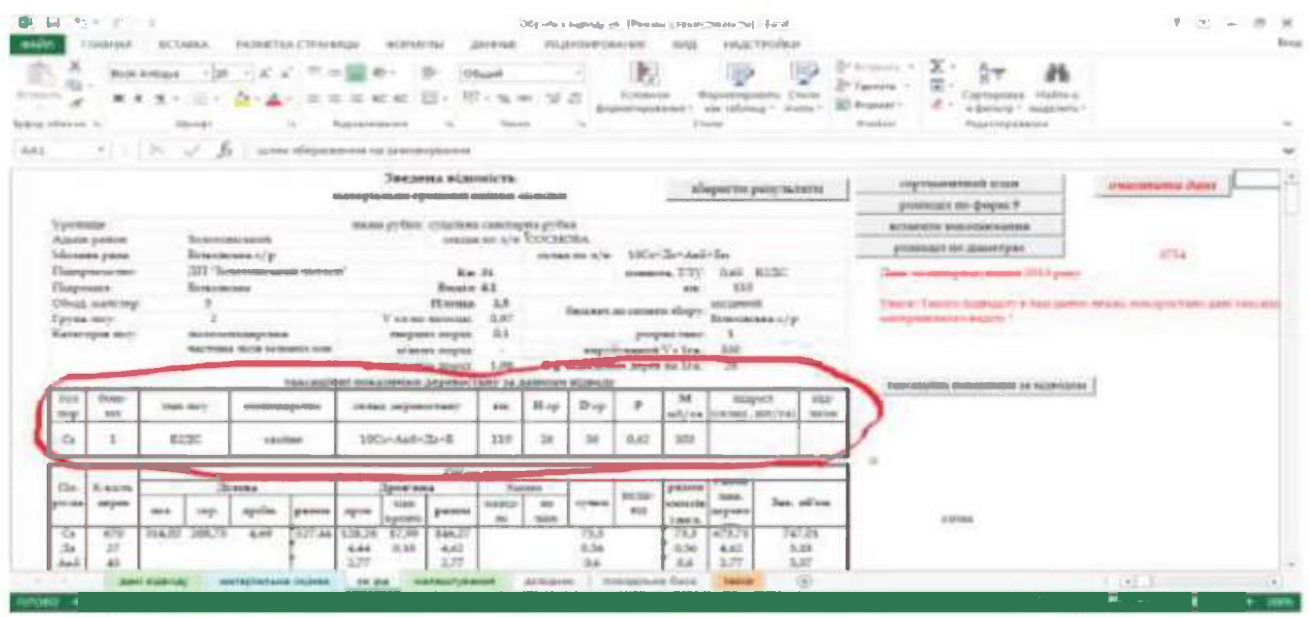

Рис. 5. Дані таксаційної характеристики за відводом 
результат, записавши його одразу в клітинку «розряд h», виділену синім маркером (див. рис. 5).

Провівши визначення розряду висот, приступали до розрахунку матеріальної оцінки лісосіки та зведеної відомості ї матеріально-грошової оцінки. Для цього з польової облікової відомості заносили дані суцільного обліку дерев в програму для обробки відводу (див. рис. 6), та натискаємо кнопку «обробка даних». Після цього програма розраховує дані, та формує відомість матеріальної оцінки лісосіки, яку вже можна роздруковувати. В цій відомості будуть розраховані значення об'єму вирубуваної деревини за кожним ступенем товщини окремо з розбиття на ділову деревину за крупністю, та дров'яну деревину, із підведенням загальних підсумків (рис. 7).

Далі натискаємо кнопку «обробка даних», як показано на рис. 8. Програма, на основі матеріальної оцінки проведе розрахунок таксової вартості деревини, згідно із затвердженими розмірами ставок збору за спеціальне використання лісових ресурсів, та сформує зведену відомість матеріальногрошової оцінки лісосіки з усіма необхідними даними, і підготує ї для друкування.

У кінці проводимо накладання результатів геодезичних знімань на планшет лісових насаджень, роздруковуємо ії та додаємо до матеріалів відводу.

Таким чином, документально оформлена лісосіка за допомогою програмного забезпечення «ИнГео» складається з:

- зведеної відомості матеріально-грошової оцінки;

- матеріальної оцінка лісосіки;

- модельних дерев для визначення розряду висот;
- польової облікової відомості.

Висновки. Впровадження ПТ-технологій у лісовому господарстві значно зменшує трудомісткість, скорочує тривалість проведення складних робіт з таксації та дозволяє оперативно визначати координати об'єктів, дає можливість оцінити об'єктивність проведення лісовпорядкування та відхилення при їх виконанні, контролювати відведення лісосік головного користування в підрозділах держлісгоспів.

\section{Література}

1. Букша И.Ф., Букша М.И. Применение мобильной ГИС-технологии Field-Мар в лесном и садово-парковом хозяйстве / Науковий вісник НЛТУ України. 2013. Вип. 23.5. С 28-34.

2. Горошко М.П., Молочний П.М. Інформаційні технології в організації і веденні лісового господарства Розточчя / Науковий вісник УкрдЛТУ. 2005. Вип. 15.2. С. 14-18.

3. Гром М.М. Таксація насаджень: Навчальний посібник. Львів: УкрдлТУ, 2002. $187 \mathrm{c.}$.

4. Ильючик М.А. Оценка состояния древостоев по аэрокосмическим изображениям. URL: http: //www.bioscience.ru.

5. Инструментальная геоинформационная система "ИнГео". URL: http: // www. integro.ru/projects/gis/main_gis.htm

6. Лопатин Е. К вопросу об автоматизированной актуализации информации о лесном фонде по космическим снимкам. URL: http://www.forgis.ru/ publications/forest_actualization.

7. Матеріали безперервного лісовпорядкування по дп "Золотоніський лісгосп" за 2009-2013 роки. 216 с.

8. Швиденко А.Й. Нормативно-справочные материалы для таксации лесов Украины и Молдавии. К.: Урожай, 1987. 560 с.

9. Матеріали відводів ділянок під рубку головного користування на 2016 рік по "Золотоніський лісгосп". 111 с.

10. «Правила рубок головного користування в лісах України» затверджені наказом Державного комітету лісового господарства України 23.12.2009 p. № 364. К. 2009. 12 c.

$$
\text { Обробка відводу.хls }\left[\mathrm{P}_{1}\right.
$$

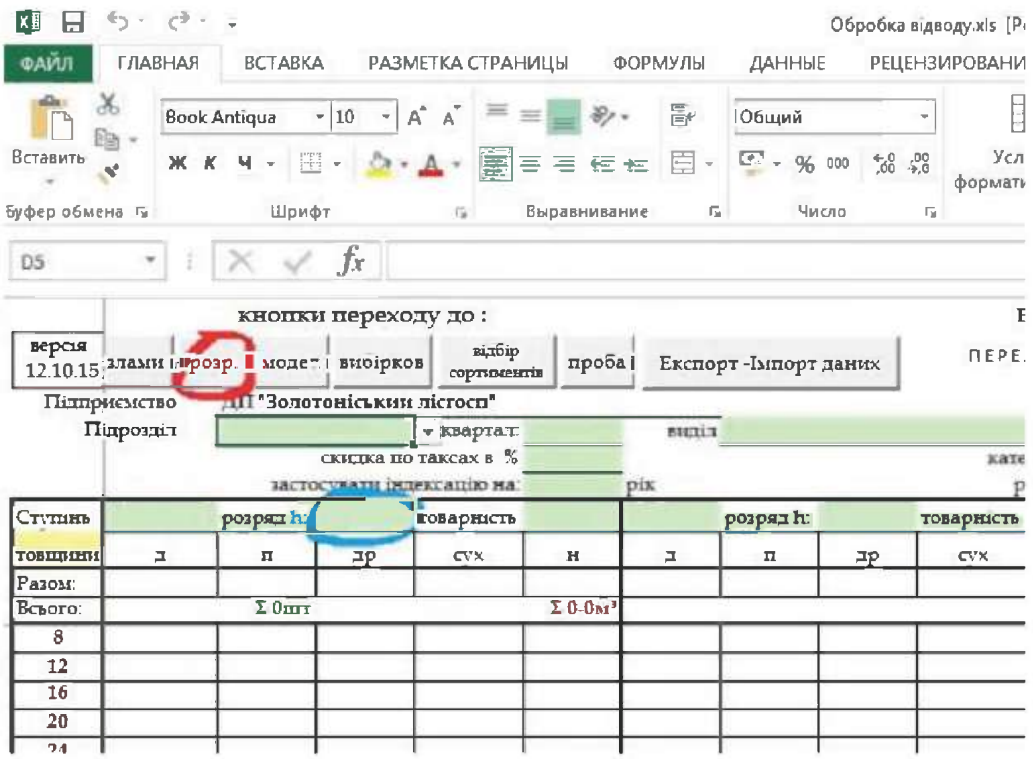

Рис. 6. Фукціональна кнопка для визначення розряду висот

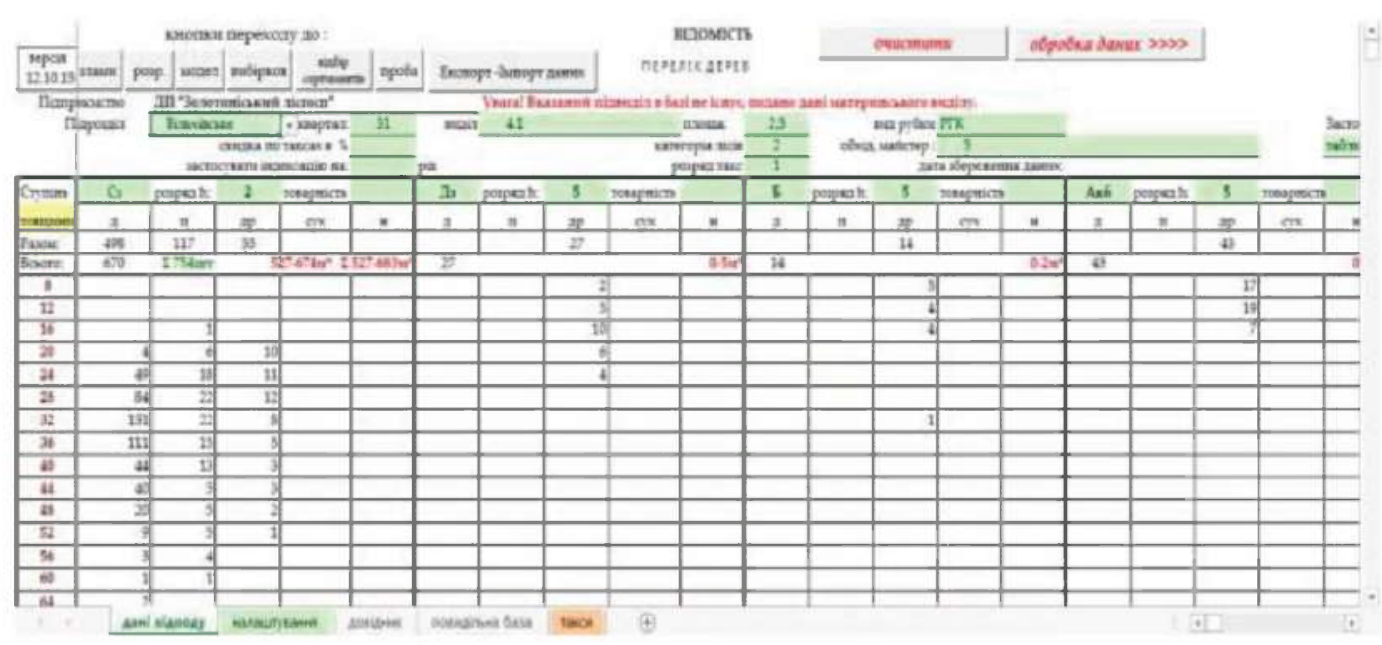

Рис. 7. Дані суцільного обліку занесені до програми 


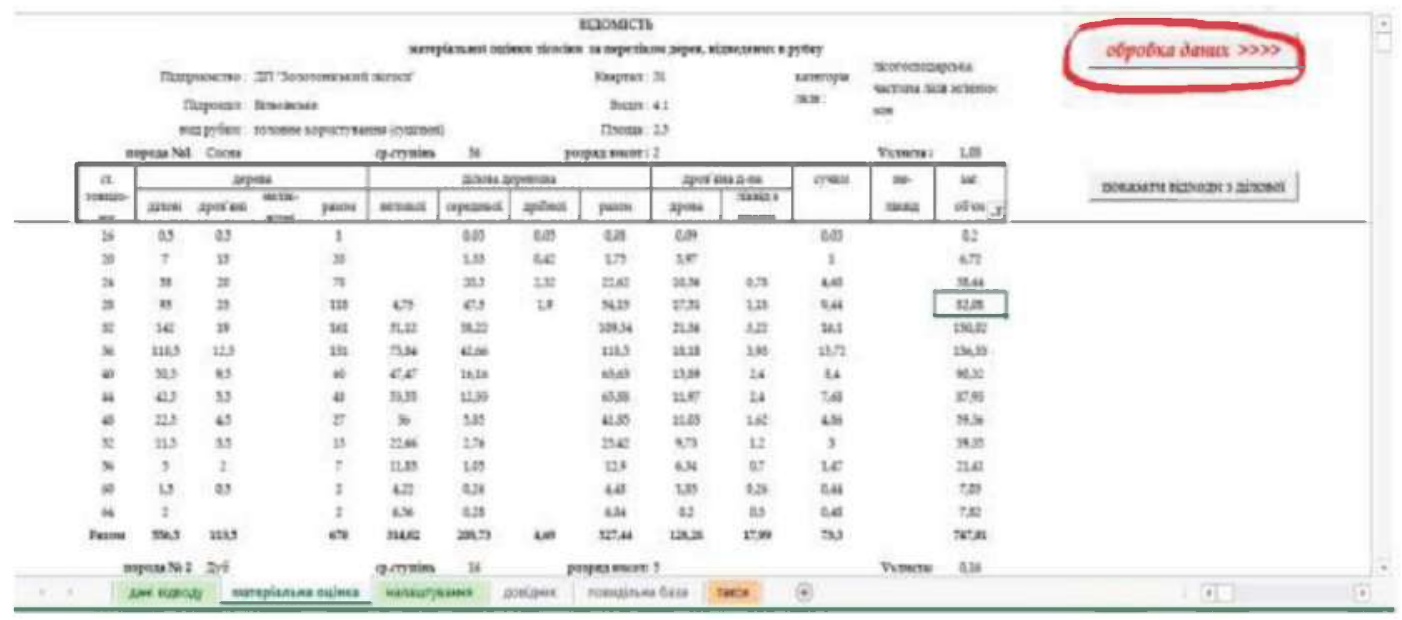

Рис. 8. Відомість матеріальноІ оцінки

11. Світличний О.О., Плотницький С.В. Основи геоінформатики. Суми: ВТД «Університетська книга», 206. 295 с.

12. Ткач В.П., Полупан А.В., Костяшкін С.Н. Інформаційні технології в лісовій галузі // Лісовий і мисливський журнал. 2003. № 1. С. 10-12.

\section{References}

1. Buksha I.F., Buksha M.I. Application of mobile GIS-technology Field-Map in forestry and landscape gardening // Scientific Herald of NFU of Ukaraine 2013. - Rel. 23.5. P 28-34.

2. Goroshko M.P., Milochny P.M. Information technologies in the organization and management of forestry in Roztochya// Scientific Herald of USLU. 2005. Ref. 15.2. P. $14-18$

3. Hrom M.M. Taxation of plants: Tutorial. Lviv: USLU. 2002. $187 \mathrm{p}$.

4. YI'yuchyk M.A. Estimation of the state of the stands by aerospace images. URL: http: //www.bioscience.ru.

5. Instrumental geoinformation system "InGeo". URL: http://www.integro. ru/projects/gis/main_gis.htm
6. Lopatin E. On the issue of automated updating of information on the forest fund on space images. URL: http://www.forgis.ru/ publications/forest actualization

7. Materials of continuous forest management on the state enterprise "Zolotonsky forestry" for 2009-2013. 216 p.

8. Normative reference materials for forest taxation in Ukraine and Moldova / Shvydenko A.Y. etc. K.: Urozhay, 1987. 560 p.

9. Material of drafts of plots under the main cut-off for 2016 by "Zolotonosha forestry". $111 \mathrm{p}$.

10. "Rules of cutting of main use in forests of Ukraine" approved by the order of the State Committee of Forestry of Ukraine 23.12.2009 p. № 364. K. 2009. $12 \mathrm{p}$.

11. Svitlychny O.O., Plotnitsky S.V. Fundamentals of Geoinformatics. Sumy: VTD "University Book", 206. 295 p.

12. Tkach V.P., Polupan A.V., Kostyashkin S.N. Information technologies in the forest industry // Forest and hunting magazine. 2003. No. 1. P. 10-12. 